\title{
PENGARUH MODEL PEMBELAJARAN ADVANCE ORGANIZER MENGGUNAKAN VIDEO PEMBELAJARAN TERHADAP HASIL BELAJAR FISIKA PESERTA DIDIK KELAS XI
}

\author{
Nurul Hamdanillah, Ahmad Harjono, Susilawati \\ Program Studi Pendidikan Fisika \\ FKIP, Universitas Mataram \\ Jalan Majapahit No. 62, Mataram \\ Email: nhamdanillah@gmail.com
}

\begin{abstract}
This research is aimed to identify the effect of advance organizer learning model through video learning towards physics learning outcome of second grade students MIA SMAN 2 Labuapi. Advance Organizer is a learning model which consists of 3 phases: presentation of Advance Organizer, presentation of learning assignment or learning of material, and strengthen the cognitive structure. There are three domains of learning objective concerned in the study, which are, first cognitive aspect from C1 until C6 (knowledge, comprehension, application, analysis, synthesis and evaluation), second is affective aspect and the last is psychomotor aspect. The student cognitive learning outcome was done by using objective test. Based on data analysis, $t_{\text {count }}>t_{\text {table }}$, as the result, the null hypothesis $\left(H_{o}\right)$ is rejected and the alternative hypothesis $\left(H_{a}\right)$ is accepted that there was the influence of advance organizer learning model through video learning towards physics learning outcome of second grade students MIA SMAN 2 Labuapi.
\end{abstract}

Keywords: Advance organizer, video learning, physics learning outcome

\section{PENDAHULUAN}

Fisika merupakan ilmu tentang alam dalam makna yang terluas. Fisika mempelajari gejala alam yang tidak hidup atau materi dalam lingkup ruang dan waktu (Prasetyo, Wahyana, Mundilarto, Subiakto \& Abdullah. 2004:4.3). Pembelajaran fisika di SMA/MA terdapat dua hal yang berkaitan dengan fisika yang tidak terpisahkan, yaitu fisika sebagai produk (berupa fakta, konsep, prinsip, hukum, dan teori) dan fisika sebagai proses (kerja ilmiah). Pelajaran fisika adalah pelajaran yang mengajarkan berbagai pengetahuan yang dapat mengembangkan daya nalar, analisa sehingga hampir semua persoalan yang berkaitan dengan alam dapat di mengerti (Sinulingga \& Munte, 2012).

Hasil observasi di sekolah SMAN 2 Labuapi, terdapat beberapa masalah yang muncul diantaranya, pelajaran fisika kebanyakan disuguhkan dalam bentuk persamaan matematis, sehingga pemahaman konsep dalam pembelajaran fisika peserta didik kurang, dan menyebabkan hasil belajar pun rendah, hal ini disebabkan kurang bervariasinya guru dalam memilih model pembelajaran yang didominasi oleh pembelajaran konvensional. Pembelajaran konvensional ini menggunakan metode ceramah dan guru langsung memberikan latihan soal pada peserta didik, di mana pembelajaran berpusat pada guru (teacher center) dan peserta didik menjadi pasif dan kurang interaktif dalam proses belajar mengajar.

Masalah selanjutnya adalah kurangnya perhatian guru terhadap pengetahuan awal yang dimiliki oleh peserta didik. Muammar, Harjono dan Gunawan (2015), Pengetahuan awal (prior knowledge) merupakan salah satu karakteristik peserta didik. Keberagaman latar belakang dan pengalaman menyebabkan pengetahuan awal masing-masing tidaklah sama. Pengetahuan awal yang didapatkan peserta didik sebelum pembelajaran mempengaruhi proses belajar 
secara signifikan. Pernyataan ini didukung oleh Rahmatiah, Koes \& Kusairi. (2016) mengatakan bahwa pengetahuan awal peserta didik berperan penting dalam belajar karena menunjang kemudahan peserta didik dalam menerima dan memahami suatu materi atau konsep baru dalam pembelajaran. pengetahuan awal perlu digali oleh guru guna memunculkan pengetahuan yang dibentuk oleh peserta didik agar struktur kognitifnya tertata dengan baik.

$$
\text { Upaya mengatasi permasalahan }
$$

pembelajaran tersebut diperlukan suatu inovasi model pembelajaran. Salah satu model pembelajaran menurut peneliti yang memberikan peluang peserta didik dalam mengatasi pengetahuan awal untuk dapat memahami konsep fisika dan meningkatkan hasil belajar adalah model pembelajaran advance organizer. Harjono (2012) mengatakan bahwa advance organizer merupakan cara yang paling efisien untuk menghubungkan materi baru dengan konsep yang sesuai dengan struktur kognitif. Bulkis, Talwil \& Azis (2014) juga mengatakan bahwa advance organizer dirancang untuk memperkuat pengetahuan awal peserta didik tentang pelajaran tertentu dan bagaimana mengelola, memperjelas dan memelihara pengetahuan awal tersebut dengan baik sehingga mampu menolong peserta didik mengingat kembali yang telah dipelajari dan memindahkan pengetahuan (struktur kognitif) tersebut ke materi yang baru agar menuju pembelajaran bermakna, dengan demikian peserta didik akan mudah memahami pelajaran dan akan meningkatkan kemampuan berpikirnya dengan baik.

Kualitas suatu proses pembelajaran, selain dipengaruhi oleh model pembelajaran juga dipengaruhi oleh media pembelajaran. Diperlukan media pembelajaran yang dapat merangsang pikiran, perasaan dan perhatian dari peserta didik pada saat proses belajar mengajar berlangsung. Salah satu media pembelajaran yang dapat meningkatkan kemampuan penalaran dan perhatian peserta didik, dapat dilatih dengan meningkatkan daya visualisasi dengan menggunakan video pembelajaran fisika. Video pembelajaran dapat membuat belajar fisika lebih menarik, interaktif dan komunikasi yang lebih menekankan pada proses pembentukan pengetahuan secara aktif, serta mampu mempertahankan perhatian peserta didik selama proses belajar (Resta, 2013).

Video merupakan salah satu jenis media pembelajaran yang menggunakan gambar, suara, dan beberapa animasi sebagai ilustrasi kejadian dari materi yang dipelajari, dengan harapan produk (pengembangan media video) ini dapat memberikan gambaran nyata tentang apa yang dipelajari oleh peserta didik (Rozie, 2013). Gunawan (2015) juga berpendapat bahwa video pembelajaran dapat digunakan membimbing peserta didik untuk memahami sebuah materi melalui visualisasi.

Model pembelajaran advance organizer menekankan pada aspek pengorganisasian pengetahuan awal yang bertujuan memperkuat struktur kognitif peserta didik, sedangkan video pembelajaran dapat membuat belajar lebih menarik dan interaktif. Model pembelajaran advance organizer disajikan dalam bentuk video pembelajaran dapat menarik perhatian peserta didik untuk lebih fokus dalam belajar, sehingga tujuan pembelajaran dapat dicapai dengan efektif. Perpaduan dari model pembelajaran advance organizer dengan video pembelajaran diharapkan mampu memberikan pengaruh yang signifikan terhadap hasil belajar fisika peserta didik.

\section{METODE PENELITIAN}

Jenis penelitian yang digunakan adalah kuasi eksperimen untuk mencari pengaruh variabel tertentu dengan variabel lain dalam kondisi dikendalikan. Penelitian ini melibatkan variabel bebas yaitu model pembelajaran advance organizer menggunakan video pembelajaran dan variabel terikat yaitu hasil 
belajar fisika peserta didik. Populasi pada penelitian ini adalah seluruh peserta didik kelas XI MIA SMAN 2 Labuapi. Desain penelitian yang digunakan dalam penelitian ini yaitu rancangan kelompok non-ekuivalen atau disebut juga dengan untreated control group design with pretest and postest. Tabel 1 berikut menunjukkan desain penelitiannya.

Tabel 1 Desain Penelitian

\begin{tabular}{llll}
\hline Kelompok & Pretest & Perlakuan & Posttest \\
\hline Eksperimen & $\mathrm{O}_{1}$ & $\mathrm{X}$ & $\mathrm{O}_{2}$ \\
\hdashline Kontrol & $\mathrm{O}_{3}$ & $\mathrm{O}_{4}$ \\
\hline & &
\end{tabular}

Keterangan:

$\mathrm{O}_{1}$ : Pemberian Pretest pada kelas yang diajar dengan model pembelajaran advance organizer menggunakan video pembelajaran

$\mathrm{O}_{2}$ : Pemberian Posttest pada kelas yang diajar dengan model pembelajaran advance organizer menggunakan video pembelajaran

$\mathrm{O}_{3}$ : Pemberian Pretest pada kelas yang diajar dengan pembelajaran konvensional

$\mathrm{O}_{4}$ : Pemberian Posttest pada kelas yang diajar dengan pembelajaran konvensional

$X$ : Pemberian perlakuan dengan model pembelajaran advance organizer menggunakan video pembelajaran

Teknik pengambilan sampel yang digunakan adalah Teknik sampling jenuh, karena kelas MIA hanya memiliki dua kelas saja yaitu kelas XI MIA 1 dan XI MIA 2, sehingga kedua kelas populasi akan menjadi sampel. Instrument yang digunakan dalam penelitian ini berupa tes. Tes yang akan digunakan dalam penelitian ini untuk mengukur hasil belajar fisika peserta didik berupa tes obyektif berbentuk pilihan ganda sebanyak 25 butir soal dengan lima pilihan jawaban, guna mengukur hasil belajar fisika peserta didik pada ranah kognitif $\left(\mathrm{C}_{1}\right.$ sampai $\left.\mathrm{C}_{6}\right)$, sedangkan untuk ranah afektif (sikap) berupa lembar observasi, dan psikomotorik (keterampilan) menggunakan penilaian unjuk kerja. Uji analisis data menggunakan uji-t polled varians, dengan derajat kebebasan $(\mathrm{dk})=\mathrm{n}_{1}+\mathrm{n}_{2}-2$ dan $\alpha=0,05$.

\section{HASIL PENELITIAN DAN PEMBAHASAN}

\section{A. Hasil Penelitian}

Untuk mencari hasil belajar fisika peserta didik menggunakan tes pilihan ganda sebanyak 25 soal. Soal-soal yang diberikan adalah soal yang telah lulus uji instrumen. Sebelum diberikan perlakuan kepada kedua kelas tersebut, terlebih dahulu dilakukan tes awal untuk mengetahui kemampuan awal peserta didik. Pada akhir pertemuan, dilakukan tes akhir untuk mengetahui hasil belajar peserta didik baik pada ranah kognitif, afektif dan psikomotor.

1. Hasil Tes Awal

Tabel 2. Hasil Tes Awal

\begin{tabular}{ccc}
\hline \multirow{2}{*}{ Deskripsi } & \multicolumn{2}{c}{ Tes Awal } \\
& Kontrol & Eksperimen \\
\hline Jumlah siswa & 26 & 27 \\
Rata-rata & 30.00 & 34.52 \\
Nilai tertinggi & 48.00 & 48.00 \\
Nilai terendah & 16.00 & 16.00 \\
\hline
\end{tabular}

\section{Hasil Tes Akhir}

Hasil tes akhir, pada ranah kognitif, ranah afektif dan ranah psikomotor selama proses pembelajaran berlangsung pada kedua kelas, sebagai berikut.

\subsection{Hasil Belajar Ranah Kognitif}

Terdapat perbedaan rata-rata hasil tes akhir peserta didik pada kedua kelompok sampel. Sesudah diberi perlakuan, nilai ratarata tes akhir kelas eksperimen adalah 76,00 sedangkan untuk kelas kontrol adalah 68,77. Hasil tes akhir ranah kognitif pada kedua kelompok sampel disajikan pada Tabel 3.

Tabel 3. Hasil Tes Akhir

\begin{tabular}{ccc}
\hline \multirow{2}{*}{ Nilai } & \multicolumn{2}{c}{ Kelas } \\
\cline { 2 - 3 } & Kontrol & Eksperimen \\
\hline Jumlah siswa & 26 & 25 \\
Rata-rata & 68.77 & 76.00 \\
Tertinggi & 88.00 & 92.00 \\
Terendah & 48.00 & 60.00 \\
\hline
\end{tabular}




\subsection{Hasil Belajar Ranah Afektif}

Terdapat perbedaan rata-rata hasil tes akhir pada ranah afektif kelas kontrol dan kelas eksperimen, yang tersaji pada Gambar 1.

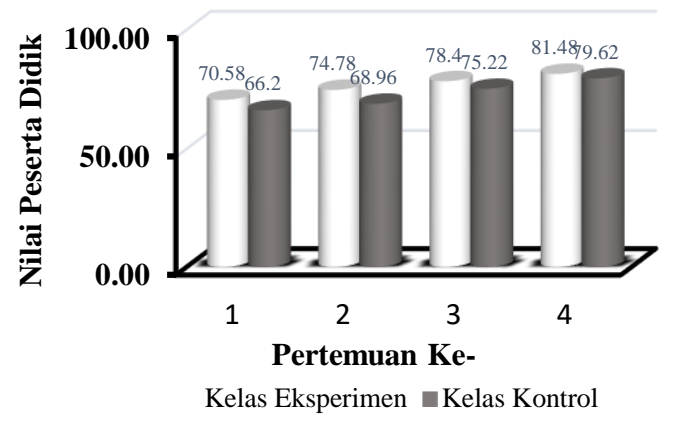

Gambar 1. Perbandingan Hasil Belajar Pada Ranah Afektif Kelas Eksperimen dan Kelas Kontrol

\subsection{Hasil Belajar Ranah Psikomotor}

Terdapat perbedaan rata-rata hasil tes akhir pada ranah psikomotor kelas eksperimen dan kelas kontol, yang tersaji pada Gambar 2.

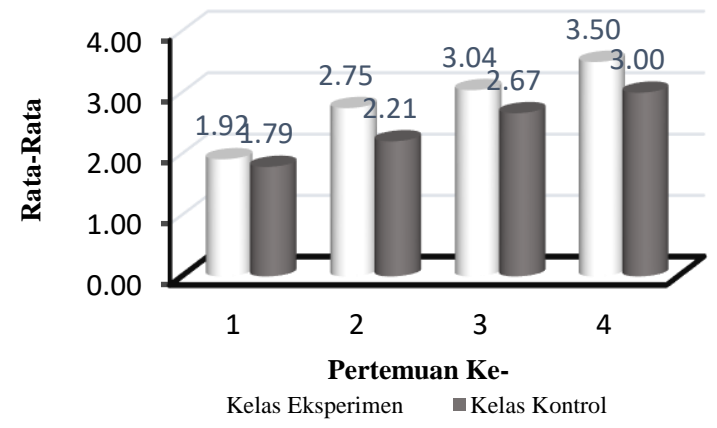

Gambar 2. Perbandingan Hasil Belajar

Psikomotor Kelas Eksperimen dan Kelas Kontrol

\section{B. Pembahasan}

Penelitian ini dilakukan di SMAN 2 Labuapi, dengan menguji coba instrumen hasil belajar terlebih dahulu, yang dilakukan di kelas XII IPA 1, pada tanggal 22 Juli 2017, peserta didik yang melakukan uji coba instrumen sebanyak 23 orang. Hasil uji coba instrumen tersebut menghasilkan 28 soal yang valid, 6 soal yang ditolak dan 1 soal yang direvisi, sehingga jumlah soal untuk pemberian tes awal maupun tes akhir pada peserta didik dipilih sebanyak 25 soal.

Penelitian dilakukan di kelas XI MIA SMAN 2 Labuapi dengan menggunakan dua kelompok sampel, yaitu kelas kontrol dan kelas eksperimen. Kelas kontrol menggunakan pembelajaran konvensional, sedangkan kelas eksperimen mengunakan model pembelajaran advance organizer menggunakan video pembelajaran. Analisis data dilakukan berdasarkan hasil tes awal (pre-test) dan tes akhir (post-test) pada kedua kelompok sampel. Hasil penelitian, manunjukkan bahwa nilai rata-rata tes awal peserta didik pada kelas eksperimen sebesar 34,52 dan kelas kontrol sebesar 30,00. Berdasakan uji homogenitas dari data tes awal hasil belajar menyatakan bahwa kedua kelas homogen dan terdistribusi normal. Hasil perhitungan ini dapat dikatakan bahwa kelas eksperimen dan kelas kontrol memiliki kemampuan awal yang sama. Nilai rata-rata kemampuan awal peserta didik ini rendah jika dibandingkan dengan nilai KKM, rata-rata tersebut dikategorikan tidak tuntas. Sebab, kedua kelompok sampel belum memperoleh materi suhu, kalor, dan perpindahan kalor yang sesuai dengan jenjang pendidikannya, melainkan peserta didik hanya menerima materi pengenalan pada jenjang SMP dan kurangnya kemampuan awal peserta didik untuk menghubungkan pengetahuan yang lama dengan pengetahuan baru dan bagaimana mengkonstrusikan pengetahuan tersebut. Nilai rata-rata dari kedua kelompok sampel ini akan menjadi tolak ukur untuk melihat peningkatan hasil belajar peserta didik pada tes akhir setelah diberikan perlakuan.

Hasil tes akhir didapatkan, nilai rata-rata hasil belajar fisika kelas eksperimen sebesar 76,00 dengan nilai tertinggi 92,00 dan nilai terendah 60,00 . Kelas kontrol nilai rata-rata tes akhir sebesar 68,77 dengan nilai tertinggi 88,00 dan nilai terendah 48,00. Berdasarkan hasil uji homogenitas kedua kelas adalah homogen dan data terdistribusi normal, selanjutnya dilakukan analisis data uji hipotesis menggunakan uji-t polled varians didapatkan $t_{\text {hitung }}>t_{\text {tabel }}$ pada taraf signifikan 5\%. Hasil uji statistik (ujit) yang telah dilakukan menunjukkan bahwa 
peningkatan nilai rata-rata kelas eksperimen lebih tinggi dari pada kelas kontrol, dibandingkan dengan kemampuan awal peserta didik. Model pembelajaran advance organizer menggunakan video pembelajaran yang diterapkan pada kelas eksperimen memberi pengaruh yang signifikan terhadap hasil belajar peserta didik dibandingkan dengan pembelajaran konvensional yang diterapkan di kelas kontrol.

Hasil penelitian mengenai kemampuan kognitif hasil belajar terdapat beberapa temuan lain, baik itu pengaruh desain pembelajaran advance organizer dan desain pembelajaran berbantuan. Hasil penelitian yang dilakukan Amanah, Harjono dan Gunade (2017) menyatakan bahwa Pemberian advance organizer di awal pembelajaran ternyata sangatlah efektif, karena dapat memberikan gambaran dan jalan tersendiri bagi peserta didik untuk menyelesaikan masalah yang diberikan. Sani dan Maryono (2011) menyatakan bahwa terdapat perbedaan yang signifikan antara hasil belajar fisika siswa yang diajar dengan model pembelajaran advance organizer dengan hasil belajar fisika siswa yang diajar melalui metode pembelajaran yang konvensional pada materi tekanan di kelas VIII semester 1 SMP Cerdas Murni T.P 2010/2011. Temuan Harjono (2012) menunjukkan adanya interaksi strategi pembelajaran dan pemberian advance organizer terhadap hasil belajar fisika peserta didik. Temuan Kumar, Seefan dan Pratjojo (2014) menyatakan bahwa terdapat pengaruh model pembelajaran advance organizer berbantuan animasi flash terhadap hasil belajar siswa pada materi teori kinetik gas kelas XI IPA SMA Negeri 1 Comal Pemalang. Wahyuni dan Sulistiyo (2017) mengatakan bahwa media pembelajaran Compact Dist Interactive (CD-i) berbasis video scribe menggunakan model pembelajaran advance organizer pada mata pelajaran TKB kelas X TAV di SMK Negeri 3 Surabaya, dinyatakan efektif dalam meningkatkan ketuntasan belajar siswa.
Temuan-temuan para peneliti tersebut membuktikan bahwa model pembelajaran advance organizer merupakan jembatan penolong dalam menggali pengetahuan awal yang dimiliki oleh peserta didik, dan mampu mengolah suatu informasi atau pengetahuan baru dengan mengaitkan pengetahuan lama yang sudah dimiliki menjadi suatu struktur kognitif yang utuh sehingga hasil belajar meningkat dan terjadi proses belajar yang bermakna.

Pengetahuan awal merupakan pengetahuan yang dibangun oleh peserta didik sebelum proses pembelajaran, yang dimana pengetahuan awal ini perlu digali oleh guru untuk dapat memunculkan pengetahuan yang dibentuk oleh peserta didik. Berdasarkan lembar observasi kegiatan yang telah dilakukan oleh peneliti di dalam kelas eksperimen, pada sintak pertama penyajian advance organizer, bertujuan untuk mengasah kemampuan awal peserta didik, yang dilakukan dengan bantuan video pembelajaran. Mengasah kemampuan awal peserta didik, perlu dilakukan untuk mengetahui tingkat pemahaman peserta didik dalam materi yang akan diajarkan, dengan demikian peserta didik akan mudah memahami pelajaran dan akan meningkatkan kemampuan berpikirnya dengan baik, sehingga pembelajaran bermakna dapat terjadi. Seperti dalam penelitian Harjono (2011) yang mengatakan bahwa ada perbedaan hasil belajar fisika siswa yang memiliki prior knowledge yang tinggi dan kelompok siswa yang memiliki prior knowledge rendah.

Pembelajaran bermakna merupakan suatu proses mengaitkan informasi baru pada konsep-konsep relevan yang terdapat dalam struktur kognitif seseorang. Seperti yang dikatakan oleh Harjono (2012) bahwa advance organizer dapat membantu agar informasi lebih bermakna (meaningful) dengan menghubungkan pengetahuan sebelumnya dengan pengetahuan baru dan berfungsi sebagai intellectual scaffolding. Konsep ini 
menjelaskan bahwa dalam diri peserta didik sudah ada organisasi dan kejelasan tentang pengetahuan dibidang subjek tertentu. Organisasi yang dimaksud sebagai struktur kognitif dan struktur ini menentukan kemampuan peserta didik untuk menangani berbagai ide dan hubungan baru. Berdasarkan hasil penelitian ini dapat dilihat bahwa model pembelajarn advance organizer menggunakan video pembelajaran memberi pengaruh yang positif dalam mengasah kemampuan awal, untuk dapat meningkatkan hasil belajar.

Sintak kedua, berdasarkan hasil observasi kegiatan, peneliti telah melakukan langkahlangkah sesuai dengan kegiatan pembelajaran yang disusun. Penyampaian materi diberikan melalui video pembelajaran, membuat peserta didik menjadi antusias dalam mendengarkan dan menyimak materi yang disampaikan. Urutan materi yang dibuat dengan cara progressive differenssial, yang dimulai dengan menjelaskan hal-hal yang umum kemudian ke hal-hal yang khusus. Penyajian bahaan ajar, selanjutnya dengan cara diskusi kelompok menggunakan LKPD, yang dapat membantu peserta didik untuk memiliki pengalaman belajar yang nyata dan aktif, sehingga peserta didik dapat lebih memahami konsep-konsep pada materi suhu, kalor, dan perpindahan kalor.

Sintak ketiga, berdasarkan lembar observasi kegiatan, peneliti juga mengikuti urutan-urutan kegiatan pembelajaran yang telah disusun. Fase ini bertujuan untuk terjadinya proses rekonsiliasi integratif, maksudnya adalah dapat menjelaskan dan menunjukkan secara jelas perbedaan dan penerimaan materi yang baru dengan materi yang telah dijelaskan terlebih dahulu dan telah dikuasai oleh peserta didik. Peneliti dalam hal ini melakukan dengan cara miminta peserta didik untuk membedakan aspek-aspek materi yang dipelajari, kemudian meminta peserta didik untuk mengungkapkan secara lisan inti materi dan merangkum semua materi yang didapat pada saat penyajian materi maupun pada saat diskusi kelompok. Tahap terakhir mengklarifikasi jawaban yang diberikan oleh peserta didik dengan menarik kesimpulan melalui video pembelajaran, sehingga proses rekonsiliasi integratif dapat terwujud dengan baik dan membantu peserta didik dalam menyimpan informasi yang didapat dengan baik di dalam struktur kognitifnya.

Ketiga sintak yang dimiliki oleh advance organizer, dalam penelitian ini melibatkan video pembelajaran di dalamnya, dimana video pembelajaan ini membantu dalam pengorganisasian pengetahuan awal, kemudian dalam penyajian materi pembelajaran, dan memperkuat struktur kognitif. Peran dari video pembelajaran ini penting dalam mewujudkan proses pembelajaran yang bermakna. Melalui video pembelajaran dapat menfokuskan perhatian peserta didik dalam menerima pelajaran dan mampu menjelaskan materi melalui visualisasi. Pertanyataan ini didukung oleh Gunawan (2015) yang menyatakan bahwa video pembelajaran dapat digunakan dalam membimbing peserta didik untuk memahami sebuah materi melalui visualisasi. Resta (2013) mengatakan bahwa video pembelajaran memiliki beberapa manfaat diantaranya, dapat meningkatkan motivasi belajar sehingga materi mudah dipahami, merubah prilaku perserta didik agar lebih berkonsentrasi, membawa kesegeran, hasil belajar lebih bermakna, memberikan umpan balik, menambah pengalaman, dan menambah wawasan.

Pembelajaran konvensional yang diterapkan dikelas kontrol, kurang berpengaruh terhadap hasil belajar fisika peserta didik, karena menggunakan metode ceramah dan langsung membahas contoh soal, sehingga peserta didik menjadi kurang aktif dan proses pembelajaran hanya berpusat pada guru. Hal inilah, yang menyebabkan pemahaman konsep fisika menjadi rendah yang berdampak pada hasil belajar fisika yang rendah.

Berdasarkan lembar observasi yang telah di amati dan di nilai oleh observer selama proses pembelajaran untuk ranah afektif dan 
psikomotor, menunjukan bahwa model pembelajaran advance organizer menggunakan video pembelajaran berpengaruh pada ranah afektif dan ranah psikomotor yang signifikan, jika dibandingkan dengan pembelajaran konvensional yang diterapkan di kelas kontrol. Pada kelas eksperimen dan kelas kontrol samasama melakukan praktikum menggunakan lembar kerja peserta didik (LKPD) yang telah disediakan selama empat kali pertemuan.

Hasil penilaian ranah afektif pada kelas eksperimen dan kelas kontrol, menunjukkan terdapat perbedaan yang signifikan selama proses pembelajaran, peserta didik pada kelas eksperimen memiliki rata-rata yang lebih tinggi dari pada kelas kontrol yaitu 76,31 dan 72,55. Hal tersebut, karena peserta didik pada kelas eksperimen dituntut untuk aktif dalam proses belajar, dibandingkan dengan kelas kontrol yang pasif dimana proses belajarnya berpusat pada guru, sehingga peserta didik menjadi kurang bersemangat dalam proses belajar. Menurut Supardi (2015), proses pembelajaran pada ranah afektif menekankan pada bagaimana kepribadian peserta didik bersikap dan bertingkah laku serta menghargai orang lain selama proses pembelajaran. Berdasarkan hasil pengamatan yang dilakukan observer selama kegiatan pembelajaran, peneliti menyimpulkan bahwa hasil belajar fisika pada ranah afektif, peserta didik pada kelas eksperimen lebih baik dari pada kelas kontrol. Pernyaaan ini didukung oleh Tasiwan, Nugroho dan Hartono (2014) memiliki temuan perbedaan yang sangat signifikan dalam motivasi dan sikap sains peserta didik yang menggunakan advance organizer berbasis proyek dibandingkan dengan kelas yang tidak menggunakan advance organizer berbasis proyek.

Aspek yang dinilai pada ranah psikomotor meliputi jenjang menirukan, memanipulasi, pengalamiahan, dan artikulasi. Hasil pengamatan yang telah dilakukan, menunjukkan bahwa keterampilan peserta didik selama kegiatan pembelajaran mengalami peningkatan yang baik pada setiap pertemuan, baik pada kelas eksperimen maupun kelas kontrol. Pada pertemuan pertama, peserta didik yang belum terbiasa melakukan percobaan, terlihat kaku dan bingung. Peserta didik kurang terampil dalam menggunakan alat praktikum, sehingga membutuhkan bimbingan dari guru. Pada pertemuan selanjutnya, peserta didik sudah cukup terbiasa melakukan percobaan. Supardi (2015) juga menyatakan bahwa pembelajaran keterampilan akan efektif bila dilakukan dengan menggunakan prinsip belajar sambil mengerjakan (learning by doing) dan keterampilan yang dilatih melalui praktik secara berulang-ulang akan menjadi kebiasaan. Hasil observasi jika dibandingkan pada setiap pertemuan, nilai rata-rata kelas eksperimen lebih tinggi dibandingkan dengan kelas kontrol. Hal ini, karena model pembelajaran advance organizer menggunakan video pembelajaran memberi hal-hal positif seperti peserta didik lebih semangat serta lebih berkonsentrasi selama praktikum berlangsung. Pernyataan ini didukung oleh Hakim dan Harahap (2013:41) yang mengatakan bahwa penerapan model pembelajaran advance organizer dengan pemberian LKS terstruktur berdasarkan teori APOS dapat meningkatkan aktivitas proses belajar mengajar. Pada kelas kontrol yang menggunakan pembelajaran konvensional mimiliki nilai rata-rata yang baik juga selama empat pertemuan, namun masih di bawah nilai rata-rata kelas eksperimen, karena diawal proses pembelajaran peserta didik cenderung pasif, sehingga ketika praktikum dilaksanakan peserta didik yang masih kurang memahami langkah-langkah praktikum, sungkan untuk bertanya yang menyebabkan hasil praktikum kurang maksimal.

Berdasarkan teori yang telah ada, hasil penelitian sebelumnya dan hasil penelitian peneliti terbukti memiliki kecocokan. Hasil penelitian menunjukkan bahwa model pembelajaran advance organizer menggunakan 
video pembelajaran memberi pengaruh yang signifikan terhadap hasil belajar fisika peserta didik kelas XI MIA SMAN 2 Labuapi. Pengaruh pada hasil belajar tidak hanya pada ranah kognitif saja, namun pada ranah afektif dan ranah psikomotor juga memberi dampak yang positif dan signifikan.

\section{KESIMPULAN}

Berdasarkan hasil penelitian, analisis data, dan pembahasan, dapat disimpulkan bahwa, terdapat pengaruh model pembelajaran advance organizer menggunakan video pembelajaran terhadap hasil belajar fisika peserta didik kelas XI MIA SMAN 2 Labuapi. Pengaruh tersebut menunjukkan adanya peningkatan hasil belajar pada materi suhu, kalor, dan perpindahan kalor, baik pada ranah kognitif (C1 sampai C6), ranah afektif dan ranah psikomotor. Pengaruh tersebut juga menunjukkan bahwa, setiap sintak yang ada pada model pembelajaran advance organizer diterapkan dengan baik, sehingga proses pembelajaran pun menjadi bermakna.

\section{REFERENSI}

Amanah, D. P., Harjono, A., \& Gunada, W., I. 2015. Kemampuan Pemecahan Masalah Dalam Fisika Dengan Pembelajaran Generative Berbantuan Scaffolding Dan Advance Organizer. Jurnal Pendidikan Fisika dan Teknologi, 3(1), 84-91.

Bulkis, Talwil, M. \& Azis, A. 2014. Penerapan Pendekatan Pembelajaran Advance Organizer Untuk Meningkatkan Keterampilan Berpikir Kritis Dan Pemahaman Konsep Fisika Pada Peserta Didik Kelas VIII SMP Negeri 1 Ma'rang Kabupaten Pangkep. Jurnal Sains dan Pendidikan Fisika, 10(3), 314-323.

Gunawan. 2015. Model Pembelajaran Sains Berbais ICT. Mataram: FKIP Universitas Mataram.

Harjono, A. 2011. Pengaruh Strategi Pembelajaran dan Pemberian Advance Organizer serta Prior Knowledge terhadap Hasil Belajar Fisika Siswa Kelas X. Disertasi, Program Studi Teknologi Pembelajaran, Program Pascasarjana, Universitas Negeri Malang.

Harjono, A. 2012. Perbedaan Strategi Pembelajaran dan Pemberian Advance Organizer Pengaruhnya Terhadap Hasil Belajar Fisika Siswa Kelas X. Jurnal Pijar MIPA, 7(1), 13-17.

Hakim, R. A \& Harahap, B. M. 2013. Upaya Penguatan Struktur Kognitif Siswa Melalui Model Pembelajaran Advance Organizer Dengan Pemberian LKS Terstruktur Berdasarkan Teori APOS. Jurnal Online Pendidikan Fisika, 2(1), 33-41.

Kumar, Seefan, J. \& Pratjojo. 2014. Pengaruh Model Pembelajaran Advance Organizer (AO) Berbantuan Animasi Flash Terhadap Hasil Belajar Teori Kinetik Gas Siswa Kelas XI IPA SMA Negeri 1 Comal-Pemalang. Jurnal Pendidikan Fisika, 1(5), 255-260.

Muammar, H., Harjono, A., \& Gunawan. 2015. Pengaruh Model Pemebelajaran Assure Dan Pengetahuan Awal Terhadap Hasil Belajar IPA-Fisika Siswa Kelas VII SMPN 22 Mataram. Jurnal Pendidikan Fisika dan Teknologi, 1(3), 166-172.

Prasetyo, Z. K, Wahyana, Mundilarto, Subiakto, \& Abdullah, A.A. 2004. Materi

Pokok Kapita Selekta Pembelajaran Fisika. Jakarta: Universitas Terbuka.

Rahmatiah, R., Koes, S. H. \& Kusairi, S. 2016. Pengaruh Scaffolding Konseptual Dalam Pembelajaran Group Investigation Terhadap Prestasi Belajar Fisika Siswa SMA Dengan Pengetahuan Awal Berbeda. Jurnal Pendidikan Fisika Dan Teknologi, 2(2), 45-54.

Rozie, F. 2013. Pengembangan Media Video Pembelajaran Daur Air Untuk Meningkatkan Proses Dan Hasil Belajar IPA Siswa SD. Jurnal Pendidikan Sains, 1(4), 413-424.

Resta, L. I., Fauzi, A. \& Yulkifli. 2013. Pengaruh Pendekatan Pictorial Riddle 
Jenis Video Terhadap hasil Belajar Siswa Dalam Pembelajaran Inkuiri Pada Materi gelombang Terintegrasi Bencana Tsunami. Jurnal Pillar Of Physics Education, 1(1), 17-22.

Sani, A. R. \& Maryono. 2011. Perbedaan Hasil Belajar Siswa Dengan Pembelajaran Advance Organizer Terhadap Hasil Belajar Dengan Pembelajaran Konvensional Pada Materi Fisika Topik Tekanan Dikelas VIII SMP Cerdas Murni Tembung Kabupaten Deli Serdang. Jurnal Fisika Inovasi Pembelajaran Fisika, 3(1), 43-48.

Sinulingga, K. \& Munte, D. 2012. Pengaruh Model Pembelajaran Advance Organizer Berbasis Mind Map Terhadap Hasil Belajar Fisika Siswa Pada Materi Pokok Besaran Dan Satuan Di Kelas X. Jurnal Pendidikan Fisika, 1(2), 1-6.

Supardi. 2015. Penilaian Autentik Pembelajaran Afektif, Kognitif, dan Psikomotor; Konsep dan Aplikasi. Jakarta: PT Raja Grafindo Persada.

Wahyuni, N. \& Sulistiyo, E. 2017. Pengembangan media pembelajaran Compact Dist Interactive (CD-i) berbasis video scribe menggunakan model pembelajaran advance organizer pada mata pelajaran TKB kelas X TAV di SMK Negeri 3 Surabaya. Jurnal Pendidikan Teknik Elektro, 6(2), 161166. 